\title{
Changes in Physical Properties of Bovine Milk from the Colostrum Period to Early Lactation
}

\author{
A. Tsioulpas, ${ }^{*}$ A. S. Grandison, $\dagger$ and M. J. Lewis $\dagger^{1}$ \\ *School of Land, Crop and Food Sciences, University of Queensland, Brisbane 4072, Queensland, Australia \\ †School of Food Biosciences, University of Reading, PO Box 226, RG6 6AP, Reading, United Kingdom
}

\begin{abstract}
The aim of this study was to analyze individual cows' samples from the colostrum, postcolostrum, and early lactation periods to investigate how milk composition, physical properties, stability, and suitability for processing change throughout this period. Attention was paid to the first week postpartum in which the composition of bovine mammary secretion can change markedly. Properties including $\mathrm{pH}$, titratable acidity, ethanol stability (ES), rennet clotting time, and casein micelle size were analyzed, together with some compositional factors such as fat, total protein, lactose, total and ionic calcium, magnesium, citrate, phosphorus, sodium, and potassium. Total $\mathrm{Ca}(36.2 \mathrm{mM})$ and free ionic $\mathrm{Ca}(2.58 \mathrm{~m} M), \mathrm{Mg}(5.9 \mathrm{mM}), \mathrm{P}(32.2 \mathrm{mM})$, and $\mathrm{Na}(24.1 \mathrm{mM})$ appeared to be high on d 5 postpartum, having decreased substantially over the first $5 \mathrm{~d}$; they gradually decreased thereafter. The average $\mathrm{pH}$ on d 5 was only 6.49 , compared with 6.64 at 1 mo postpartum. Stability measurements showed that the average ES on d 5 was $70 \%$ and the rennet clotting time was $12.2 \mathrm{~min}$, which were significantly lower than values at later stages. A number of milk properties including ES, $\mathrm{pH}$, protein content, and $\mathrm{Ca}^{2+}$ concentration could be useful for identifying the point of transition from colostrum to the early lactation period. Knowing the composition and physical properties of colostrum and postcolostrum secretions will help establish when such milk is suitable for processing and determine the best use for that milk.
\end{abstract}

Key words: colostrum, early lactation, casein micelle stability, ionic calcium

\section{INTRODUCTION}

Colostrum is the initial milk secreted by bovines during parturition and the first few days after birth. It

Received March 12, 2007.

Accepted July 26, 2007.

${ }^{1}$ Corresponding author: m.j.lewis@reading.ac.uk provides protection to the immune system of newborn calves and provides passive immunity against pathogens. Its composition and physical properties depend on various factors including the age of the animal, number of lactation cycles, breed, diet, and diseases. Even though changes in composition and physical properties of normal bovine milk throughout lactation have been studied extensively (White and Davies, 1958a,b,c; Cerbulis and Farrell, 1976; Donnelly and Horne, 1986; Horne et al., 1986; Rodriguez et al., 2001), little is known with respect to the composition and stability of colostrum and postcolostrum milk. It has been reported that the $\mathrm{pH}$ of colostrum is lower (Edelsten, 1988), the specific gravity slightly higher (Haggag et al., 1991), and the immunoglobulin (IgG) content about 100 times $(100 \mathrm{mg} / \mathrm{mL}$ ) greater than that of normal milk (Renner et al., 1989). In the study of Klimes et al. (1986), it was found that constituents such as $\mathrm{Ca}, \mathrm{Mg}, \mathrm{P}, \mathrm{Na}$, and $\mathrm{K}$ were much greater at the first milking postpartum. Because colostrum exhibits some extreme physical properties, contamination of raw milk with colostrum could be an important issue for the dairy industry because it could affect milk processability. The elevated protein and mineral content might render milk unsuitable for certain food processing operations (such as UHT or milk powder production) and incompliant with regulations regarding milk composition for processing. In addition, increased levels of IgG can lead to reduced heat stability and weak curd formation (Feagan, 1979). According to Zawistowski and Mackinnon (1993), the presence of high levels of bovine IgG could adversely affect the human immune system.

The purpose of this study was therefore to report on the changes occurring from colostrum to early lactation in individual samples and to comment on the stability and suitability of milk for processing.

\section{MATERIALS AND METHODS}

Samples were collected from the University's farm (Reading, UK) every day (early morning milking) from 8 animals, transported to the laboratory, and stored at $4^{\circ} \mathrm{C}$. All animals used in this study were Friesians; they 
had been through the dry period between October and December and did not show any health problems during the experimental period. Samples were collected on the first $5 \mathrm{~d}$ postpartum and then on selected days (d 15, 30, 60, and 90).

Analyses including $\mathrm{pH}$, titratable acidity, ethanol stability (ES), rennet clotting time (RCT), micelle size, gross composition, and the concentrations of $\mathrm{Na}, \mathrm{K}, \mathrm{Ca}$ and $\mathrm{Ca}$ ions were carried out during the first $2 \mathrm{~d}$ to ensure that analyses reflected the composition of fresh milk.

In this study, the colostrum period was defined as the time from the first milking of the cow to $\mathrm{d} 5$ of lactation; the postcolostrum period was the period from d 6 to 30 of lactation. Beyond this point, and up to $90 \mathrm{~d}$, all samples were characterized as early lactation milks.

\section{Physical Properties}

$\boldsymbol{E S}$. The stability of milk to ethanol was determined by mixing equal volumes $(2 \mathrm{~mL})$ of milk and a range of ethanol solutions (water/ethanol from 40 to $100 \%$, vol/ vol, at $2 \%$ intervals), and examining for the presence of clots when poured into a Petri dish. Depending upon the formation of clots, ethanol solutions of increasing or decreasing concentration were used, and the strongest concentration of ethanol that did not cause coagulation was defined as the ES. Analyses were performed at room temperature $\left(20 \pm 1^{\circ} \mathrm{C}\right)$.

$\boldsymbol{R C T}$. Five milliliters of milk was poured in a glass test tube and maintained in a $30^{\circ} \mathrm{C}$ water bath. The sample was left at $30^{\circ} \mathrm{C}$ for $10 \mathrm{~min}$, and then $13 \mu \mathrm{L}$ of freshly prepared chymosin (Chymax Plus, Chr. Hansen, Denmark), which was diluted 1:10 with distilled water, was added. The time ( $\mathrm{min}$ ) from thorough mixing to the first sign of sudden breakdown of the film on the test tube wall was measured and defined as the RCT.

Casein Micelle Diameter. A light scattering technique was used to determine the average size of casein micelles using a Zetasizer Malvern System 3000 (Malvern Instruments Ltd., Worcestershire, UK). Samples were defatted by centrifugation at $1,410 \times g$ for $30 \mathrm{~min}$ before analysis. Skim milk was diluted 50 times with double distilled water, placed in a $3-\mathrm{mL}$ plastic cuvette, and analyzed.

\section{Chemical Analyses}

Fat, total protein, and lactose contents were measured using a DairyLab II Analyzer (Multispec Limited, York, UK) based on absorption of near infrared radiation at different wavelengths.

For the determination of titratable acidity (TA), 1 $\mathrm{mL}$ of phenolphthalein indicator (concentrated) was added to $10 \mathrm{~mL}$ of milk, and the mixture was titrated with $0.111 M \mathrm{NaOH}$ to a permanent faint pink color, which was the titration end-point $(\mathrm{pH}$ 8.3). The TA was expressed as lactic acid concentration using the following relationship: \% lactic acid $(\mathrm{wt} / \mathrm{vol})=0.1 \times$ titer volume $(\mathrm{mL})$.

The concentration of $\mathrm{P}$ was determined using a British Standard method (British Standards, 1992). Total citrate concentration was measured following the improved method of White and Davies (1963). Total Ca and $\mathrm{Mg}$ concentrations were determined using the method of Murthy and Rhea (1966), employing a Pye Unicam SP9 Atomic Absorption Spectrophotometer (Pye Unicam Ltd., Cambridge, UK).

For the determination of free $\mathrm{Ca}$ ion concentration, a Ciba Corning $634 \mathrm{ISE} \mathrm{Ca}^{2+} / \mathrm{pH}$ Analyser (Ciba Corning, Newbury, UK) was used. Measurements were performed at room temperature $\left(20 \pm 1^{\circ} \mathrm{C}\right)$. The operation and principle of determination have been described previously (Lin et al., 2006).

Sodium and $\mathrm{K}$ concentrations were measured using a 348 RapidLab (Ciba Corning Diagnostic Limited 2001). The principle of determination was the same as for the Ciba Corning 634.

\section{Statistical Analysis}

Mean values, number of determinations, and standard deviation were calculated using SPSS software (SPPS, Chicago, IL). The comparison between mean values was done using Student's $t$-test at a significance level of $P<0.05$. In all other relationships, the threshold levels of $P<0.05,0.01$, and 0.001 were used to investigate the degree of significance.

\section{RESULTS AND DISCUSSION}

Table 1 presents average values and standard deviations $(n=8)$ for physical properties and composition for all individual samples collected on selected days over the first $90 \mathrm{~d}$ postpartum. Changes were generally substantial over the first $5 \mathrm{~d}$ and although less remarkable, some changes occurred between 5 and $90 \mathrm{~d}$. The $\mathrm{pH}$ was very low initially and increased steadily thereafter. Klimes et al. (1986) found similar values for $\mathrm{pH}$ in the first $5 \mathrm{~d}$ postpartum although their $\mathrm{pH}$ value for the first milking was slightly higher than that found in the current study. At d 5 postpartum, the $\mathrm{pH}$ was $6.49 \pm$ 0.10 , which was well below the value of 6.63 measured in our previous study for a complete lactation year (Tsioulpas et al., 2007) or 6.60 measured by Edelsten (1988). According to Edelsten (1988), $\mathrm{pH}$ values $<6.5$ in milk indicate the presence of some colostrum, although low $\mathrm{pH}$ values could also occur due to bacterial contamina- 
Table 1. Mean values and standard deviation of $\mathrm{pH}$, ethanol stability (ES), rennet clotting time (RCT), titratable acidity (TA), fat, protein, lactose, ash, and casein micelle diameter of samples from the first $90 \mathrm{~d}$ of lactation ${ }^{1}$

\begin{tabular}{lccccccccc}
\hline $\begin{array}{l}\text { Time } \\
\text { (d) }\end{array}$ & pH & ES (\%) & RCT (min) & $\begin{array}{c}\text { TA }(\% \\
\text { lactic acid) }\end{array}$ & Fat $(\%)$ & Protein (\%) & Lactose (\%) & Ash (\%) & $\begin{array}{c}\text { Casein micelle } \\
\text { diameter }(\mathrm{nm})\end{array}$ \\
\hline 1 & $6.17^{\mathrm{a}} \pm 0.11$ & $53^{\mathrm{a}} \pm 4.7$ & $18.1^{\mathrm{a}} \pm 4.3$ & $0.461^{\mathrm{a}} \pm 0.05$ & $3.55^{\mathrm{a}} \pm 1.82$ & $16.12^{\mathrm{a}} \pm 1.64$ & $2.69^{\mathrm{a}} \pm 0.46$ & $1.18^{\mathrm{a}} \pm 0.17$ & $227^{\mathrm{a}} \pm 19.7$ \\
2 & $6.28^{\mathrm{a}} \pm 0.11$ & $52^{\mathrm{a}} \pm 2.8$ & $9.5^{\mathrm{b}} \pm 1.8$ & $0.279^{\mathrm{b}} \pm 0.05$ & $3.49^{\mathrm{a}} \pm 1.67$ & $5.43^{\mathrm{b}} \pm 0.24$ & $3.04^{\mathrm{b}} \pm 1.23$ & $1.00^{\mathrm{b}} \pm 0.11$ & $189^{\mathrm{b}} \pm 12.3$ \\
3 & $6.28^{\mathrm{a}} \pm 0.09$ & $52^{\mathrm{a}} \pm 4.1$ & $9.3^{\mathrm{b}} \pm 0.9$ & $0.253^{\mathrm{b}} \pm 0.03$ & $4.50^{\mathrm{b}} \pm 1.54$ & $4.54^{\mathrm{c}} \pm 0.40$ & $3.52^{\mathrm{c}} \pm 0.44$ & $0.93^{\mathrm{c}} \pm 0.05$ & $198^{\mathrm{b}} \pm 9.0$ \\
4 & $6.38^{\mathrm{b}} \pm 0.07$ & $59^{\mathrm{b}} \pm 2.9$ & $9.5^{\mathrm{b}} \pm 0.8$ & $0.231^{\mathrm{bc}} \pm 0.02$ & $4.26^{\mathrm{b}} \pm 2.19$ & $4.41^{\mathrm{c}} \pm 0.31$ & $3.82^{\mathrm{c}} \pm 0.19$ & $0.92^{\mathrm{c}} \pm 0.08$ & $198^{\mathrm{b}} \pm 22.5$ \\
5 & $6.49^{\mathrm{b}} \pm 0.10$ & $70^{\mathrm{b}} \pm 10.2$ & $12.2^{\mathrm{c}} \pm 3.0$ & $0.202^{\mathrm{c}} \pm 0.02$ & $3.89^{\mathrm{c}} \pm 1.04$ & $4.23^{\mathrm{c}} \pm 0.24$ & $4.15^{\mathrm{d}} \pm 0.24$ & $0.87^{\mathrm{d}} \pm 0.04$ & $188^{\mathrm{b}} \pm 19.6$ \\
15 & $6.58^{\mathrm{c}} \pm 0.05$ & $76^{\mathrm{c}} \pm 3.8$ & $14.0^{\mathrm{d}} \pm 2.8$ & $0.185^{\mathrm{c}} \pm 0.03$ & $3.66^{\mathrm{a}} \pm 1.22$ & $4.01^{\mathrm{d}} \pm 0.43$ & $4.32^{\mathrm{de}} \pm 0.14$ & $0.83^{\mathrm{d}} \pm 0.04$ & $194^{\mathrm{b}} \pm 12.8$ \\
30 & $6.64^{\mathrm{d}} \pm 0.10$ & $78^{\mathrm{d}} \pm 5.7$ & $15.8^{\mathrm{d}} \pm 4.4$ & $0.142^{\mathrm{d}} \pm 0.02$ & $3.72^{\mathrm{d}} \pm 0.27$ & $3.08^{\mathrm{e}} \pm 0.19$ & $4.54^{\mathrm{e}} \pm 0.21$ & $0.80^{\mathrm{c}} \pm 0.06$ & $196^{\mathrm{b}} \pm 20.5$ \\
60 & $6.71^{\mathrm{d}} \pm 0.01$ & $86^{\mathrm{d}} \pm 0.0$ & $18.3^{\mathrm{e}} \pm 5.2$ & $0.145^{\mathrm{d}} \pm 0.00$ & $3.95^{\mathrm{c}} \pm 2.14$ & $2.94^{\mathrm{e}} \pm 0.19$ & $4.61^{\mathrm{e}} \pm 0.12$ & $0.76^{\mathrm{c}} \pm 0.00$ & $198^{\mathrm{b}} \pm 48.1$ \\
90 & $6.70^{\mathrm{d}} \pm 0.11$ & $85^{\mathrm{d}} \pm 7.5$ & $18.9^{\mathrm{e}} \pm 3.7$ & $0.160^{\mathrm{d}} \pm 0.02$ & $3.51^{\mathrm{a}} \pm 0.40$ & $3.20^{\mathrm{e}} \pm 0.22$ & $4.70^{\mathrm{e}} \pm 0.14$ & $0.79^{\mathrm{c}} \pm 0.01$ & $196^{\mathrm{b}} \pm 29.2$ \\
\hline
\end{tabular}

${ }^{\mathrm{a}-\mathrm{e}}$ Means in the same column without a common letter differ significantly $(P<0.05)$.

${ }^{1}$ Mean values of 8 individual cows' samples.

tion. Therefore, results from the present study indicate that after $5 \mathrm{~d}$, milk might still contain sufficient colostrum for it to be unsuitable for certain processing operations (taking into account that bacterial contamination has not occurred). The TA was also high and dropped to normal levels only after $2 \mathrm{wk}$. Titratable acidity measures components that exert some buffering capacity, in addition to lactic acid; these include proteins, phosphates, citrates, and carbon dioxide. In the present study, TA exhibited a good logarithmic relationship with total proteins $(\mathrm{r}=0.95, P<0.001)$ and with $\mathrm{P}(\mathrm{r}=$ $0.91, P<0.001)$. An inverse linear relationship with citrate $(\mathrm{r}=-0.67, P<0.01)$ was also found.

Ethanol stability during d 1 to 4 was low for cows' milk and had only achieved $70 \%$ by d 5 . Such low stability values $(<60 \%)$ are common in fresh goats' milk; this has been associated with excessive sediment formation after UHT treatment and fouling of heat exchangers (Zadow et al., 1983; Prakash et al., 2007; A. Tsioulpas and M. J. Lewis, unpublished data). The average ES $( \pm$ SD) in the present study was $76 \pm 3.1$ on $d 15$. According to Shew (1981), cows' milk should be stable at $74 \%$ ethanol to be suitable for UHT treatment. Thus, after $15 \mathrm{~d}$, postpartum milk can be processed for UHT according to our results. It is not possible to ascertain the exact day of milk suitability, because no samples were withdrawn between $\mathrm{d} 5$ and 15 . Figure 1 shows that ES was low and almost constant for the first $3 \mathrm{~d}$, after which it gradually increased.

According to Table 1, the average diameter of casein micelles was almost constant throughout the study except for the transition from d 1 to 2 , during which time it dropped from 227 to $189 \mathrm{~nm}$. The high protein (casein) and $\mathrm{Ca}$ (especially $\mathrm{Ca}^{2+}$ ) concentrations on the first day might have contributed to the incorporation of more casein in the micelles, creating larger micelles.

The total protein (Table 1) in colostrum declined rapidly from $16.1 \pm 1.64 \%$ at $d 1$ to $5.43 \pm 0.24 \%$ on $d 2$ and then continued to decrease until $30 \mathrm{~d}$, at which time it reached normal levels $(3.08 \pm 0.19 \%)$. The high protein content observed during early postpartum was not unusual and has been reported before (Foley et al., 1972; Sodhi et al., 1996). The data of Hadjipanayiotou (1995) showed a curved relationship with respect to CP during the first $11 \mathrm{~d}$ postpartum. Protein, during this period, consists of greater amounts of casein and globulins. The high proportion of Ig in colostrum provides the young calf with sufficient of this protein to develop a passive immunity system against common calfhood diseases.

There was no particular trend observed for the fat content, which varied throughout the sampling period (Table 1).

Lactose content was very low on $\mathrm{d} 1$ and increased thereafter up to $60 \mathrm{~d}$, at which time it reached normal levels (Table 1).

The ash content was high on the first day postpartum and then decreased gradually thereafter. Foley et al. (1972) noted that lactose contributes to one-third of the osmotic equilibrium in milk. Furthermore, they reported that during the first day postpartum, lactose

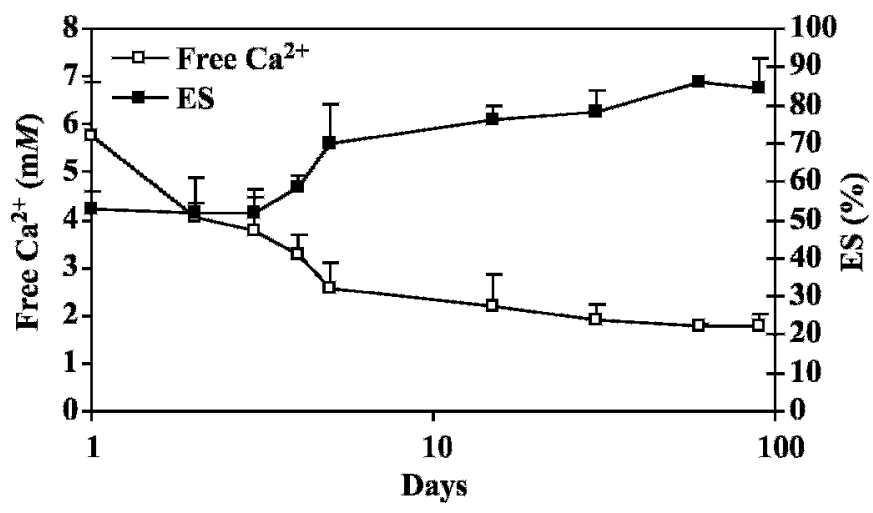

Figure 1. Changes in free $\mathrm{Ca}^{2+}$ concentration and ethanol stability (ES) during the first $90 \mathrm{~d}$ after calving. Bars represent standard deviation around the mean. 
Table 2. Mean values and standard deviation of citrate, $\mathrm{P}, \mathrm{Ca}, \mathrm{Mg}, \mathrm{Ca}^{2+}, \mathrm{Na}^{+}$, and $\mathrm{K}^{+}$of samples from the first $90 \mathrm{~d}$ of lactation ${ }^{1}$

\begin{tabular}{|c|c|c|c|c|c|c|c|}
\hline \multirow{2}{*}{$\begin{array}{l}\text { Time } \\
\text { (d) }\end{array}$} & \multicolumn{7}{|c|}{ Concentration $(\mathrm{m} M)$} \\
\hline & Citrate & $\mathrm{P}$ & $\mathrm{Ca}$ & $\mathrm{Mg}$ & $\mathrm{Ca}^{2+}$ & $\mathrm{Na}^{+}$ & $\mathrm{K}^{+}$ \\
\hline 1 & $6.62^{\mathrm{a}} \pm 2.1$ & $52.8^{\mathrm{a}} \pm 8.6$ & $54.2^{\mathrm{a}} \pm 6.7$ & $12.1^{\mathrm{a}} \pm 1.4$ & $5.75^{\mathrm{a}} \pm 1.12$ & $32.5^{\mathrm{a}} \pm 4.7$ & $40.6^{\mathrm{a}} \pm 3.5$ \\
\hline 2 & $9.62^{\mathrm{b}} \pm 1.1$ & $40.7^{\mathrm{b}} \pm 5.9$ & $39.6^{\mathrm{b}} \pm 7.5$ & $8.3^{b} \pm 2.7$ & $4.07^{\mathrm{b}} \pm 0.84$ & $30.4^{\mathrm{a}} \pm 7.7$ & $36.2^{\mathrm{b}} \pm 7.4$ \\
\hline 3 & $11.8^{\mathrm{c}} \pm 2.0$ & $36.6^{\mathrm{c}} \pm 2.1$ & $38.7^{\mathrm{b}} \pm 3.2$ & $7.0^{\mathrm{c}} \pm 2.8$ & $3.78^{\mathrm{c}} \pm 0.85$ & $26.7^{\mathrm{b}} \pm 3.9$ & $37.9^{b} \pm 4.7$ \\
\hline 4 & $11.5^{\mathrm{c}} \pm 2.1$ & $35.7^{\mathrm{c}} \pm 2.4$ & $37.8^{\mathrm{b}} \pm 3.8$ & $6.3^{\mathrm{d}} \pm 2.5$ & $3.28^{\mathrm{d}} \pm 0.40$ & $25.8^{\mathrm{b}} \pm 3.4$ & $36.5^{\mathrm{b}} \pm 4.3$ \\
\hline 5 & $10.2^{\mathrm{a}} \pm 3.3$ & $32.2^{\mathrm{d}} \pm 2.3$ & $36.2^{\mathrm{b}} \pm 3.2$ & $5.9^{\mathrm{d}} \pm 2.3$ & $2.58^{\mathrm{e}} \pm 0.54$ & $24.1^{b} \pm 2.8$ & $35.4^{\mathrm{b}} \pm 3.7$ \\
\hline 15 & $10.5^{\mathrm{ac}} \pm 1.9$ & $30.0^{\mathrm{d}} \pm 4.1$ & $33.5^{\mathrm{c}} \pm 4.1$ & $5.6^{\mathrm{d}} \pm 2.1$ & $2.18^{f} \pm 0.68$ & $22.3^{\mathrm{c}} \pm 4.0$ & $35.5^{\mathrm{b}} \pm 7.1$ \\
\hline 30 & $11.7^{\mathrm{c}} \pm 2.0$ & $25.1^{\mathrm{e}} \pm 3.8$ & $30.3^{\mathrm{c}} \pm 2.2$ & $5.2^{\mathrm{e}} \pm 3.2$ & $1.91^{\mathrm{fg}} \pm 0.35$ & $21.8^{\mathrm{c}} \pm 3.3$ & $36.3^{\mathrm{b}} \pm 2.3$ \\
\hline 60 & $12.6^{\mathrm{d}} \pm 3.7$ & $23.0^{\mathrm{e}} \pm 1.4$ & $28.3^{c} \pm 3.5$ & $4.7^{\mathrm{e}} \pm 3.5$ & $1.77^{\mathrm{g}} \pm 0.04$ & $15.9^{\mathrm{d}} \pm 3.6$ & $41.7^{\mathrm{a}} \pm 1.1$ \\
\hline 90 & $12.9^{\mathrm{d}} \pm 0.9$ & $27.4^{\mathrm{e}} \pm 1.6$ & $28.6^{c} \pm 2.1$ & $4.4^{\mathrm{e}} \pm 2.1$ & $1.78^{g} \pm 0.23$ & $17.6^{\mathrm{d}} \pm 2.9$ & $42.4^{\mathrm{a}} \pm 4.7$ \\
\hline
\end{tabular}

content is inversely proportional to the $\mathrm{K}$ concentration, to maintain the osmotic pressure in equilibrium. In the present study, there was only a slight negative correlation $(\mathrm{r}=-0.39, P<0.05)$ found between lactose and $\mathrm{K}$. In addition, lactose was negatively correlated with the Na concentration $(\mathrm{r}=-0.48, P<0.05)$. A correlation between $\mathrm{Na}$ and $\mathrm{K}$ was also shown $(\mathrm{r}=-0.55, P<0.05)$.

Mineral composition varied during the study period as shown in Table 2 . The total Ca content $(\mathrm{m} M)$ was extremely high on the first day $(54.2 \pm 6.7)$, declined sharply on the second day to $39.6 \pm 7.5$ and dropped to around $30.3 \pm 2.2 \mathrm{~m} M$ only after $30 \mathrm{~d}$. This pattern was similar for $\mathrm{Mg}$ and $\mathrm{P}$ concentrations. Free $\mathrm{Ca}^{2+}$ concentration $(\mathrm{m} M)$ declined sharply from $5.75 \pm 1.12$ to $2.58 \pm 0.54$ by d 5 . After $30 \mathrm{~d}$, it had dropped to normal levels $(1.91 \pm 0.31 \mathrm{mM})$. In another study by Sodhi et al. (1996), it was reported that the amount of ionic Ca was highly variable during the first $80 \mathrm{~h}$ postpartum; however, a slight decrease was apparent in the average ionic Ca content on the following day.

A high $\mathrm{Ca}$ ion concentration would account for low heat stability according to Parry (1974). Therefore, a value of $2.58 \mathrm{mM}$ on d 5 postpartum, which is significantly higher than the normal values reported in the literature ( $2 \mathrm{~m} M$ by Holt et al., $1981 ; 1.88 \mathrm{~m} M$ by Tsioulpas et al., 2007), would probably render milk problematic for high heat processing. Reducing ionic calcium by various methods has been found to reduce fouling during UHT treatment of milk (Prakash et al., 2007).

It has been reported (White and Davies, 1958a,b,c; Horne and Parker, 1981; Tsioulpas et al., 2007) that ES is affected by the amount of free ionized Ca in milk. According to Figure 1, the gradual increase of ES was accompanied by a respective decrease in free $\mathrm{Ca}^{2+}$. $\mathrm{Al}-$ though other factors may contribute to the changes in milk stability ( $\mathrm{pH}$, casein content), the amount of free $\mathrm{Ca}^{2+}$ is a good determinant of the ES of milk. When ES was correlated to free $\mathrm{Ca}^{2+}$, an inverse nonlinear relationship with a high $\mathrm{r}$-value was revealed $(\mathrm{r}=0.93)$. A similar pattern relationship was apparent, when RCT was plotted against the amount of ionized $\mathrm{Ca}(\mathrm{r}=0.80)$ showing that the free $\mathrm{Ca}^{2+}$ may also affect the coagulation time induced by rennet.

The high concentration of $\mathrm{Ca}$ (and $\mathrm{Ca}$ ions) observed on $\mathrm{d} 1$ postpartum is probably due to the high amounts of casein, which acts as a Ca carrier in milk (Holt, 2004).

Sodium concentration followed a similar pattern-it was high on $d 1$ and decreased thereafter. There was no particular trend regarding $\mathrm{K}$ concentration. Citrate remained at high levels $(10.9 \mathrm{mM})$ during the study period compared with the average values of around 8 $\mathrm{m} M$ reported elsewhere (Walstra and Jenness, 1984; Tsioulpas et al., 2007).

Horne and Muir (1990) investigated the relationship between ES and heat stability of milk and found that these parameters differ fundamentally because they are governed by different mechanisms of coagulation. However, Chavez et al. (2004) found that individual cow milk samples stable at ethanol solutions of $78 \%$ or greater exhibited an average heat coagulation time of $23.8 \mathrm{~min}$, whereas unstable samples (ES $\leq 72 \%$ ) coagulated just before $20 \mathrm{~min}$. In addition, Prakash et al. (2007) reported that occurrence of fouling on heat exchangers was significantly reduced when the ES of goat's milk was increased from about $58 \%$ to $>80 \%$ by the addition of stabilizers. In this case, Ca chelating agents were used to increase ethanol stability; these reduced the $\mathrm{Ca}$ ion activity and changed the mineral status of milk.

Thus, milk that is collected between 5 and $15 \mathrm{~d}$ after lactation would not be suitable for high heat treatment but could be profitably used for products such as cheese (or yogurt), where it may be beneficial due to its lower stability and faster clotting. Supporting evidence for the latter comes from the results of Table 1 in which $\mathrm{RCT}$ between 5 and $15 \mathrm{~d}$ is lower compared with values 


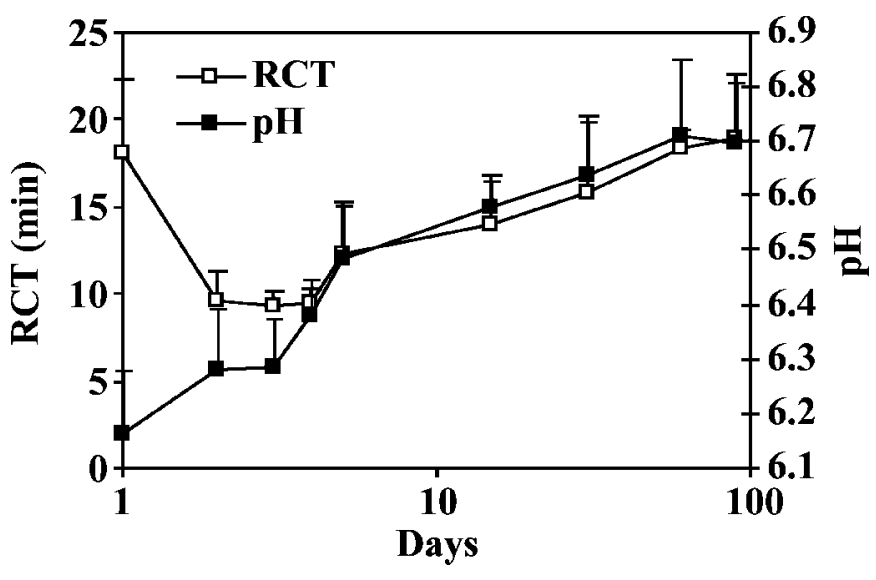

Figure 2. Changes in $\mathrm{pH}$ and rennet clotting time (RCT) during the first $90 \mathrm{~d}$ after calving. Bars represent standard deviation around the mean.

from later stages of lactation and would benefit processes requiring rapid coagulation. Colostrum samples (first $5 \mathrm{~d}$ postpartum), on the other hand, should not be used for any dairy applications, because their properties are different from normal, stable milk. Other possible uses as biological or medical material should be investigated. Figure 2 demonstrates the progression of RCT with time. It can be seen that RCT was high on the first day, decreased sharply, remained constant for the next $3 \mathrm{~d}$, and then increased steadily. It is not surprising that RCT followed a similar pattern to $\mathrm{pH}$ (except on $\mathrm{d} 1$ ) according to Figure 2, because changes in RCT can be explained by changes in $\mathrm{pH}$. Madsen et al. (2004) and Fox and McSweeney (1998) reported that $\mathrm{RCT}$ increases when $\mathrm{pH}$ increases and decreases when protein content increases. This explains the gradual increase in RCT from d 4 postpartum and thereafter. The high RCT on d 1 cannot be explained; one would expect a low RCT on $\mathrm{d} 1$, because $\mathrm{pH}$ is low and the protein level is extremely high $(\sim 16 \%)$. One suggestion is that the enzymic phase takes a long time because of the high protein to chymosin ratio, bearing in mind that coagulation does not occur until 70 to $80 \%$ of the $\kappa$-casein has been hydrolyzed.

Finally, it is interesting to note that wide variability was observed for most of the measured parameters between and within individual animals. The variation within animals can be attributed to the physiological changes that the cows are going through during the colostrum period and during the transition to the postcolostrum or early lactation periods. However, variability was also observed between animals, which can be associated with the differences in genetics, physiology, age, and number of lactation cycles of each animal. Factors including nutrition, season, or breed are not considered in the present study because all animals were of the Friesian breed, followed the same diet, and calved between October and December.

\section{CONCLUSIONS}

There are considerable changes in the physical properties of individual samples from the first day postpartum through to the early lactation period. Total $\mathrm{Ca}$ and $\mathrm{Ca}^{2+}, \mathrm{P}, \mathrm{Mg}$, and $\mathrm{Na}$ concentrations were greater during the colostrum period compared with the postcolostrum and early lactation season. The stability of milk was very low on the first day postpartum as shown by the low $\mathrm{pH}$ and $\mathrm{ES}$ and high ionic calcium concentration. Between $\mathrm{d} 1$ and $\mathrm{d} 5$ there was a steady decrease in $\mathrm{Ca}^{2+}$ concentration, accompanied by a progressive increase in ES. Rennet clotting time was short. Ethanol stability and RCT were both influenced by the amount of ionized Ca. The ES on d 5 was $70 \%$, which is below the threshold stability (74\%) for UHT processing. Therefore, such milk could lead to processing problems, related to poor heat stability, although it would have good clotting properties. Total protein was extremely high on $\mathrm{d} 1$ and dropped sharply in the next days. On the other hand, lactose content was low at the beginning of lactation and increased steadily throughout the study.

\section{REFERENCES}

British Standards. 1992. BS 1741-12: Methods for chemical analysis of liquid milk and cream-Part 12: Determination of total phosphorus content of milk. British Standards Institute, Milton Keynes, UK.

Cerbulis, J., and H. M. Farrell Jr. 1976. Composition of the milks of dairy cattle. II. Ash, calcium, magnesium, and phosphorus. J. Dairy Sci. 59:589-593.

Chavez, M. S., L. M. Negri, M. A. Taverna, and A. Cuatrin. 2004 Bovine milk composition parameters affecting ethanol stability. J. Dairy Res. 71:201-206.

Donnelly, W. J., and D. S. Horne. 1986. Relationship between ethanol stability of bovine milk and natural variations in milk compositions. J. Dairy Res. 53:23-33.

Edelsten, D. 1988. Composition of milk. Pages 175-199 in Meat Science, Milk Science and Technology. H. R. Cross and A. J. Overby, ed. Elsevier Science Publishers B.V., Amsterdam, the Netherlands.

Feagan, J. T. 1979. Factors affecting protein composition of milk and their significance to dairy processing. Aust. J. Dairy Technol. 34:77-81.

Foley, R. C., D. L. Bath, F. N. Dickinson, and H. A. Tucker. 1972. Dairy cattle: Principles, practices, problems, profits. Lea and Febiger, Philadelphia, PA.

Fox, P. F., and P. L. H. McSweeney. 1998. Dairy Chemistry and Biochemistry. 1st ed. Blackie Academic and Professional, London, UK.

Hadjipanayiotou, M. 1995. Composition of ewe, goat and cow milk and of colostrum of ewe and goats. Small Rumin. Res. 18:255-262.

Haggag, H. F., L. F. Hamzawi, and G. A. Mahran. 1991. Physicochemical properties of colostrum and clinical and subclinical mastitic buffalo milk. Egyptian J. Dairy Sci. 19:55-63.

Holt, C. 2004. An equilibrium thermodynamic model of the sequestration of calcium phosphate by casein micelles and its application 
to the calculation of the partition of salts in milk. Eur. Biophys. J. 33:421-434.

Holt, C., D. G. Dalgleish, and R. Jenness. 1981. Inorganic constituents of milk. Calculation of the ion equilibria in milk diffusate and comparison with experiment. Anal. Biochem. 113:154-163.

Horne, D. S., and D. D. Muir. 1990. Alcohol and heat stability of milk. J. Dairy Sci. 73:3613-3626.

Horne, D. S., and T. G. Parker. 1981. Factors affecting the ethanol stability of bovine milk. Effect of serum phase components. J. Dairy Res. 48:273-284.

Horne, D. S., T. G. Parker, W. J. Donnelly, and D. T. Davies. 1986. Factors affecting the ethanol stability of bovine skim milk. VII. Lactational and compositional effects. J. Dairy Res. 53:407-417.

Klimes, J., P. Jagos, J. Bouda, and S. Gajdusek. 1986. Basic qualitative parameters of cow colostrum and their dependence on season and post partum time. Acta Vet. (Brno) 55:23-39.

Lin, M.-J., M. J. Lewis, and A. S. Grandison. 2006. Measurement of ionic calcium in milk. Int. J. Dairy Technol. 59:192-199.

Madsen, B. D., M. D. Rasmussen, M. O. Nielsen, L. Wiking, and L. B. Larsen. 2004. Physical properties of mammary secretions in relation to chemical changes during transition from colostrum to milk. J. Dairy Res. 71:263-272.

Murthy, G. K., and U. Rhea. 1966. Determination of major cations in milk by atomic absorption spectrophotometry. J. Dairy Sci. 50:313-317.

Parry, R. M. 1974. Milk coagulation and protein denaturation. Pages 603-661 in Fundamentals of Dairy Chemistry. B. H. Webb, A. H. Johnson, and J. A. Alford, ed. AVI Publishing Company, Westport; Connecticut.

Prakash, S., N. Datta, M. J. Lewis, and H. C. Deeth. 2007. Reducing fouling during UHT treatment of goat's milk. Milchwissenschaft 62:16-19.

Renner, E., G. Schaafsma, and K. J. Scott. 1989. Micronutrients in milk and milk-based food products. Pages 1-70 in Micronutrients in Milk and Milk-Based Food Products. E. Renner, ed. Elsevier Science Publishing Ltd., New York, NY.

Rodriguez, E. M. R., S. M. Alaejos, and C. D. Romero. 2001. Mineral concentrations in cow's milk from the Canary Islands. J. Food Comp. Anal. 14:419-430.

Shew, D. I. 1981. Technical aspects of quality assurance. Pages 115121 in IDF Document 133, New Monograph on UHT Milk. International Dairy Federation, Brussels, Belgium.

Sodhi, S., S. P. Ahuja, and S. Singh. 1996. Changes in the levels of ionic calcium and proteins during assembly of casein micelles and transition of colostrum to milk in the buffalo and cow. Buffalo 1:101-108.

Tsioulpas, A., M. J. Lewis, and A. S. Grandison. 2007. Effect of minerals on casein micelle stability of cows' milk. J. Dairy Res. 74:1-7.

White, J. C. D., and D. T. Davies. 1958a. The relation between the chemical composition of milk and the stability of the caseinate complex. I. General introduction, description of samples, methods and chemical composition of samples. J. Dairy Res. 25:236-255.

White, J. C. D., and D. T. Davies. 1958b. The relation between the chemical composition of milk and the stability of the caseinate complex. II. Coagulation by ethanol. J. Dairy Res. 25:256-266.

White, J. C. D., and D. T. Davies. 1958c. The relation between the chemical composition of milk and the stability of the caseinate complex. III. Coagulation by rennet. J. Dairy Res. 25:267-280.

White, J. C. D., and D. T. Davies. 1963. The determination of citrate in milk and milk sera. J. Dairy Res. 30:171-189.

Walstra, P., and R. Jenness. 1984. Dairy Chemistry and Physics. Wiley, New York, NY.

Zadow, J. G., J. F. Hardham, H. R. Kocak, and J. J. Mayes. 1983. The stability of goat's milk to UHT processing. Aust. J. Dairy Technol. 38:20-23.

Zawistowski, J., and R. Mackinnon. 1993. Incidence of colostrum in raw milk. J. Food Prot. 56:625-626. 